\title{
Hungarian English language teachers' roles in the development of self-regulation: A pilot study
}

\author{
MELINDA MIKUSOVÁ* \\ Doctoral Program in Language Pedagogy, Eötvös Loránd University, Budapest, Hungary
}

(Received: November 13, 2018; accepted: March 17, 2019)

\begin{abstract}
In today's teacher-oriented and teacher-directed traditional school setting, students tend to depend on their teachers. Students expect their teachers to motivate them and to tell them what and how to learn and to what extent, which leads to the fact that students do not know how to organize and regulate their own learning. Therefore, it is important to study how teachers construct knowledge related to various aspects of the learning process, in this case self-regulation. The main aim of this article was to identify the roles teachers play in the development of self-regulation. In order to fulfill this aim, the article examined how the interviewees view the notion itself. For this purpose, four interviews were conducted with primary and secondary English language teachers in Hungary. As all these teachers come from the public education sphere, their understanding of self-regulation was compared to the Hungarian National Core Curriculum's concept of self-regulation. The results of the study showed that teachers are fully aware of the importance of self-regulation and directly, indirectly, consciously, and even unconsciously can foster its development not just during the English lessons, but also while preparing for and reflecting on their lessons. Continuous professional development and lifelong learning from the teachers' side turned out to be of essential importance. However, there is a considerable disagreement not only as to how teachers define the term self-regulation, but also when to start its development.
\end{abstract}

Keywords: self-regulation; roles of a teacher; lifelong learning; professional development

\section{INTRODUCTION}

Being a teacher requires an ongoing, never-ending, lifelong learning if one wants to keep up with the changing developments and needs of our world. Self-regulation plays an important part in this lifelong learning process and is considered to be one of the strongest determinants of success (Baumeister, Leith, Muraven, \& Bratslavsky, 1998; Zimmerman, 2000). With a profession as complex and challenging as teaching (Medgyes, 2000), selfregulation is essential, as it contributes to optimal growth in the educational profession. As Borg and Al-Busaidi (2012) highlighted, teachers' voice is usually left out from self-regulation research, which has been a popular area for some 30 years. Articles explore the topic from the students' perspectives, so they keep focusing on students' learning aspects rather than those of teachers. As Zimmerman (2008) emphasized, self-regulation can be learned and taught, and the primary setting in which this should happen is school. Therefore, teachers' views cannot be absent from such an analysis. This article aims to fill this niche by investigating what self-regulation means to language teachers.

The current Hungarian traditional school setting is highly teacher-oriented and teacher-directed (Reményi, 2016), and as a consequence of this, it is important to put teachers' continuous professional development and learning into focus (see Öveges \& Csizér's, 2018 study for further Hungarian data). Teachers can ensure that the learning process is liberating rather than oppressive (Freire, 1993). One of the ways to achieve this is by fostering the development of their students' self-regulatory skills, in other words, teaching them how to take responsibility for their own learning, so that they have greater control over what, how, and where they learn in order to fully engage in the learning process (Zimmerman \& Schunk, 2001). Therefore, the teachers' role in promoting their students' self-regulated learning (SRL) strategies is generally accepted as it helps students to develop learning skills, which provide them with assistance with any academic subject (Carneiro \& Veiga Simão, 2011). However, much depends on how teachers use their own knowledge of self-regulation and how they incorporate its principles into their own learning and teaching process. As Borg and Al-Busaidi (2012) stated - in relation to autonomy, but true for self-regulation as well - we need to examine teachers' knowledge about the given topic, because "the extent to and manner in which learner autonomy is promoted in language learning classrooms will be influenced by teachers' beliefs about what autonomy actually is, its desirability and feasibility" (p. 6).

But how do people interpret the notion of self-regulation? Reinders and Balcikanli (2011) highlighted that the topic

\footnotetext{
* Correspondence: Melinda Mikusová, Doctoral Program in Language Pedagogy, Eötvös Loránd University, ELTE, Rákóczi út 5., 1088 Budapest, Hungary; Phone: +36 20270 2540; e-mail: melinda.mikusova@gmail.com
}

This is an open-access article distributed under the terms of the Creative Commons Attribution 4.0 International License, which permitsunrestricted use, distribution, and reproduction in any medium, provided the original author and source are credited, a link to the CC License is provided, and changes - if any - are indicated. (SID_1) 
has two aspects. On one hand, self-regulation is perceived as "the ability to understand the students' learning needs and the ability to support them in their development towards autonomy" (p. 17). On the other hand, we can talk about the teacher's own self-regulation, which has been defined as the teacher's "ability to improve one's own teaching through one's own efforts," which involves both the teacher's own ability to make decisions about their teaching and about their professional development (p. 17). As Reinders and Balcikanli (2011) highlighted, making such decisions involve not just the knowledge of themselves as teachers but as learners too. Thus, we can state that developing learners' self-regulation is not possible without the teacher being selfregulated, which requires a learning process from the teachers' side. Therefore, it is pivotal to develop a shared definition of the knowledge and roles required by teachers, in order to guide their lifelong learning and professional development.

This article aims to investigate the understanding of selfregulation and the roles teachers play in its promotion in the Hungarian context. To this end, semi-structured interviews were conducted with four public school English language teachers by reporting the results of a pilot research study on the current status of SRL in compulsory Hungarian public education, focusing especially on English language teaching and comparing the results with the guidelines of the Hungarian National Curriculum (2012) on self-regulation. Overall, the article tries to demonstrate how English language teachers relate to self-regulation and the National Core Curriculum (NCC).

This study breaks new ground in several respects. The perspectives of Hungarian teachers of English of selfregulation and its incorporation into their foreign language lessons have not yet been explored, despite the fact that the notion itself might contribute to and greatly influence not just the students' but also the teachers' learning and teaching experience, by focusing on the teachers' views on their own ever-changing role in developing self-regulation. In addition, the results are compared to the guidelines of the Hungarian NCC in order to compare theory with practice, focusing mainly on the tasks, and values of public education.

\section{LITERATURE}

\section{The notion of self-regulation}

Self-regulation has been defined in different ways over the years. Montalvo and Torres (2004) explain that SRL research emerged in the mid-1980s when Zimmerman and Schunk published their series of volumes on SRL. A great deal of research on self-regulation was undertaken and it became one of the most important areas of educational practice. Boekaerts and Corno (2005, p. 200) concluded that over the past 20 years, researchers had "struggled with the conceptualization and operationalization of selfregulatory capacity, coming to the conclusion that there is no simple and straightforward definition of the construct of self-regulation."

Even though there is widespread agreement that successful and effective learners - of all ages - do self-regulate, theories of self-regulation differ in their descriptions of their various psychological dimensions (summarized in Table 1). Researchers cannot find a common ground as to whether self-regulation is a process or an action (Demetriou, 2000; Pintrich, 2000), an approach (Cohen, 1990), a capacity or ability (Collett, 2014; Lemos, 1999), or a system, which comprises a complex set of factors contributing and influencing self-regulation in learning (Zimmerman, 1989).

Boekaerts and Niemivirta (2000) perceive these differences as something useful, as it is possible to break selfregulation down into manageable units or subsystems in order to make the investigation of the issue more comprehensive.

Table 1. Definitions of self-regulation in chronological order

\begin{tabular}{|c|c|}
\hline Author & Definition \\
\hline Zimmerman (1989, p. 2) & $\begin{array}{l}\text { "Self-generated thoughts, feelings, and actions that are planned and cyclically adapted to the attainment } \\
\text { of personal goals." }\end{array}$ \\
\hline Cohen (1990, p. 10) & $\begin{array}{l}\text { "An approach wherein "learners make decisions, alone or with the help of others, about what they need } \\
\text { or want to know, how they will set objectives for learning, what resources and strategies they will use, } \\
\text { and how they will assess their progress." }\end{array}$ \\
\hline Lemos (1999, p. 3) & $\begin{array}{l}\text { "An individual's capacity to modulate behavior according to internal and external changing } \\
\text { circumstances." }\end{array}$ \\
\hline Demetriou (2000, p. 210) & $\begin{array}{l}\text { "Actions directed at modifying a system's present state or activity and which are necessary either } \\
\text { because that state (or activity) is diverting from a previously set goal or because the goal itself needs to } \\
\text { be changed." }\end{array}$ \\
\hline Pintrich (2000, p. 453) & $\begin{array}{l}\text { "An active, constructive process whereby learners set goals for their learning and then attempt to } \\
\text { monitor, regulate, and control their cognition, motivation, and behavior, guided and constrained by } \\
\text { their goals and the contextual features in the environment." }\end{array}$ \\
\hline $\begin{array}{l}\text { Hadwin, Järvelä, and Miller } \\
(2011, \text { p. 68) }\end{array}$ & $\begin{array}{l}\text { "Grounded in social cognitive theory, self-regulation is guided by environmental contexts/conditions } \\
\text { that promote individuals to adopt, develop, and refine strategies, monitor, evaluate, set goals, plan, and } \\
\text { adopt and change belief processes." }\end{array}$ \\
\hline Collett (2014, p. 431) & $\begin{array}{l}\text { "The capability of people to recognize and respond to context-situated behavioral, cognitive, or } \\
\text { metacognitive cues, ideally modifying aspects of their functioning in the particular context to meet the } \\
\text { needs signalled by these cues." }\end{array}$ \\
\hline
\end{tabular}


Moreover, it is worth noting that the main components are essentially the same, thus (meta)cognitive, motivational, and behavioral points of view are taken into account in line with the influence of the learning environments.

\section{Models of SRL}

Several models of SRL have emerged in the literature over the past 30 years. Each of these models reflects a slightly different theoretical stance and outlines a variety of processes and stages learners go through while being engaged in a learning task (Collett, 2014).

The most widely used one is Zimmerman's (2000) model. The first version, the Triadic Model of SelfRegulated Learning, which described that the interactions of personal, environmental, and behavioral determinants of SRL was developed in 1989 and has undergone some revisions over the years. In the 2000 version, only the three basic interacting phases of the model were outlined: (a) forethought phase, (b) performance or volitional control phase, and (c) self-reflection phase. The subprocesses belonging to each phase went through some changes, and the model achieved its current form only in 2009.

The current form of the model (Fig. 1) still comprises the three basic phases and their underlying subprocesses, such as self-regulated strategies and tools. The forethought phase is characterized by goal setting and strategic planning and involves all the self-motivation beliefs, such as self-efficacy, outcome expectations, task interest/value, and goal orientation, which precede efforts to act and set the stage for learning. The performance phase, occurring during learning efforts, incorporates everything related to self-control, such as the chosen learning strategy, time management, handling stress, environmental structuring, and all the self-observation strategies, which affect attention and performance. Last but not least, the self-reflection phase includes all the strategies of self-judgment (such as self-evaluation and causal attribution) and self-reaction (such as self-satisfaction), which follow the performance efforts and determine the learner's reaction to the whole experience, which, in turn, influences the subsequent learning efforts (forethought phase), thus completing the self-regulatory cycle.

To sum up, self-regulated learners can be characterized as people who actively, intentionally, and consciously control their learning from a cognitive, motivational, and behavioral point of view (Boekaerts, Pintrich, \& Zeidner, 2000). How can a teacher become one of them? Many researchers (Gordon, Dembo, \& Hocevar, 2007; Randi, 2004) see the expansion of the teacher education's curricula as a solution and believe that the integration of selfregulatory learning strategies into preservice teachers' training might influence their instructional strategies. They claim that by teaching preservice teachers how to be more selfregulated, they might be more inclined to foster the development of their students' SRL later.

\section{Self-regulation and teachers}

There are ongoing discussions about what a teacher has to do during an English language lesson in order to contribute
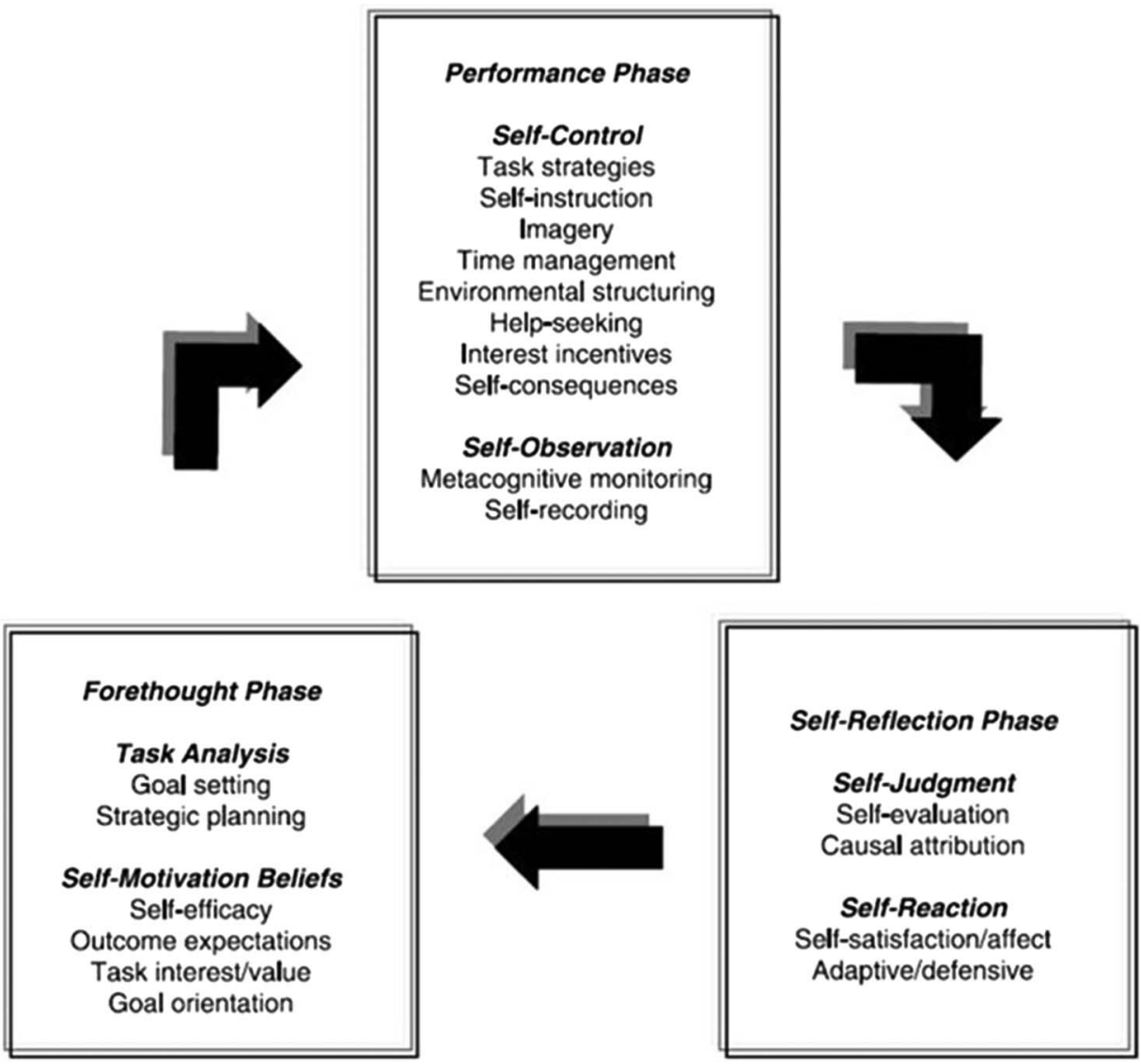

Fig. 1. Zimmerman and Moylan's Self-Regulation Model (2009, p. 300) 
to and successfully develop his/her learners' self-regulation (e.g., Borg \& Al-Busaidi, 2012; Carneiro \& Veiga Simão, 2011). However, it is still unclear how teachers develop this knowledge and the necessary practical skills. The fact that they have learned to apply self-regulatory skills and modify their own learning accordingly may help them teach the same skills to their students (Dembo, 2001). Six years earlier, Little (1995), who had been one of the first researchers to investigate the parallel between learner and teacher learning, came to the same conclusion as "language teachers are more likely to succeed in promoting learner autonomy if their own education has encouraged them to be autonomous" (p. 180).

According to Butler (2003), teachers' self-regulation can be dealt with at two levels simultaneously. On one hand, we can think of a teacher as someone self-regulating their learning about teaching, which involves the construction of "new knowledge and beliefs about teaching grounded in their coordination of theoretical frameworks and their reflection on teaching practices" (p. 5). On the other hand, teachers are learning to self-regulate their teaching practices, which are "based on specific goals for their students: teachers construct instructional strategies, enact them in their classrooms, monitor outcomes, and revise instruction accordingly" (p. 5). She notes that when teachers focus on their own learning, they revise their knowledge not just about learning but teaching as well, which, in turn, influences their teaching practice. This definition might suggest that the whole process is perceived as something that happens in a rather individualistic manner, between disconnected individuals in a formal learning environment. However, she argues that the role of collaboration, in other words, the social context, plays an essential role in teachers' understanding and development of self-regulation. Her assumptions seem to be valid, as goal setting, motivation, and reflection are continually viewed as the stages of SRL, and individuals could benefit from seeing how others have achieved their goals, the steps taken, and their reflections on the whole process. Littlejohn, Milligan, and Margaryan (2012) conducted research on knowledge workers' personal engagement in learning practices and coined a term for a collaborative mechanism called "charting" by which people self-regulate their learning. Based on this charting process, the authors created the 4C's framework, which incorporates: consuming, creating, connecting, and contributing:

- Consuming knowledge and values from sources, which have been already created by others.

- Creating new knowledge with the help of already existing knowledge, by extending, combining and argumenting.

- Connecting to others with similar goals and interests. This allows the comparison of an individual's skills and development with those of his/her peers, and allows the sharing of resources, such as experience and ideas within one's personal learning network. The peer-support and collaborative research play an important role in developing new knowledge structures.

- Contributing new knowledge, creating evidence, and publishing results of the research formally and informally, which is relevant to specific tasks and can benefit the whole collective.
This framework represents the key ways and behaviors how individuals interact in their personal learning network, in a working environment. There still remains the question of managing individual learning. One key term is goal setting, which starts with the identification of gaps in knowledge, understanding, and making further research in order to achieve them. These actions are a central part of charting, a process, and organizing principle of one's SRL.

\section{Teachers as self-regulated learners}

As highlighted above, teachers' adaptability during the lessons is crucial. However, as Dembo (2001) concluded, learning to teach is not enough; teachers have to be self-regulated themselves. As Michalsky and Schechter (2013) similarly stated, teachers' ability to develop their students' self-regulation is tied to their own self-regulation. They make a distinction between two perspectives. On one hand, the learner's perspective in SRL refers to the teacher's own learning, meaning that teachers need to learn how to learn. Therefore, in order to have autonomous learners, a teacher has to be autonomous on his/her own. Gordon et al.'s (2007) study also revealed that the way teachers learn is an important mediating factor in how they teach. On the other hand, the teacher's perspective in SRL means that teachers must be able to understand and develop self-regulated skills in their learners.

We can state that teachers are lifelong learners, and in order for professional development to influence students, teachers need to model what it means to be one (Fleming, 2011). According to Ainsworth and Eaton (2010), lifelong learning is a "way to avoid stagnation and stay current regarding changes and innovations" in various fields of life (p. 32). Therefore, it is not surprising that learning how to learn has been listed as one of the key competences for lifelong learning in the original (European Parliament \& Council of the European Union, 2006) and recently revised (European Parliament \& Council of the European Union, 2018) list of the European Council. The full list consists of eight competences needed by all individuals "for personal fulfilment and development, active citizenship, social inclusion and employment" (European Parliament \& Council of the European Union, 2006, p. 11). Many see the learning to learn competence having a pivotal role in the successful development and use of the other competencies (Mesárošová \& Mesároš, 2012). The Hungarian NCC rephrased these competencies and defined nine of them. One of these is the competence of efficient independent learning.

"Efficient and independent learning is the ability to pursue and persist in learning, organize one's own learning both individually and in groups, including effective management of time and information, to recognise one's own needs and opportunities and know the process of learning." (NCC, p. 25)

Efficient and independent learning urges students to use and apply their knowledge and skills in a variety of contexts school, home, and work - to connect these with their existing knowledge and prior life and learning experiences. For this reason, self-regulation has gained increased attention in the past couple of decades as the skills associated with it 
"are essential to cope with the challenges posed by our modern society, where knowledge is dynamic, distributed and complex" (Persico, Milligan, \& Littlejohn, 2015, p. 2482).

\section{Roles of a teacher}

Self-regulation is not an inborn characteristic, but can be developed either by natural means or by formal learning (Holec, 1981). The above-outlined Zimmerman and Moylan's (2009) model is often used in informal learning environments and focuses on the learning perspectives in SRL. However, English language teachers play an essential role in the incorporation of SRL strategies into the teaching of English, which helps their students construct their own strategies (Pintrich, 1999). The NCC (2012, p. 12) emphasizes the role of the teacher in the teaching of the "ability to pursue and persist in learning, organize one's own learning, both individually and in groups, including effective management of time and information; to recognize the needs and opportunities and to know the process of learning." It is apparent that the NCC puts a special emphasis on teaching students how to learn with teachers who play a prominent role in this process. According to Michalsky and Schenter (2013), these roles can be classified into three complementary approches: "(a) the provision of key contextual elements or task conditions that invite SRL; (b) modeling to facilitate movement from emulator (an individual who imitates a more experienced other) to self-regulator (an individual who adapts learning strategies to meet new contextual demands); and (c) direct SRL strategy instruction" (p. 63). The first approach involves the teachers' role as a facilitator. A teacher gives choices and opportunities for control, is willing to help but encourages collaboration, and is able to accept and respond to learners' needs. This, however, cannot be achieved without reflection. As Butler (2003) highlighted, both SRL and self-regulated teaching are reflective activities. By constantly reflecting on their classes, teachers can learn a lot about their students and about themselves as well. Lots of people think that reflection means nothing more than just adding a kind of thinking approach to practice. Barry and King (1998) explain the difference very clearly and make a difference between a teacher who "ponders about how well the skill, strategy, lesson, etc. is going or has gone" and compares it to the one who, according to them, is much more of a professional evaluator and "systematically reflects on a lesson" (p. 409). According to Hoffman-Kipp, Artiles, and López-Torres (2003), reflection contributes to the development of teaching expertise in the classroom and thus it supports professional development. Reflecting is an important part of not just professional practice (Sparks-Langer \& Colton, 1991) but as Calderhead (1989) emphasizes, it should be an essential part of teacher education. The problem is that reflection is not frequently built into teacher education and the structure of teaching [for a recent Hungarian overview on teacher education and preservice teachers' motivation, see Smid (2018), and Kálmán (2018) for Hungarian English teachers' motivation in corporate contexts].

The second and third pedagogical approach points to the fact that teachers can support and foster the development of their students' self-regulatory skills in both direct and indirect ways (Paris \& Paris, 2001). The former indicates a situation when teachers concretely model a strategy use and give explicit instructions, whereas the latter is used when they structure their lessons in a way that their students have the opportunity to discover these learning strategies themselves. However, in practice, teachers tend to provide their students with unguided practice. Teachers should provide their students with clarification about the classroom strategies used, explaining the type of strategy, and why, how, when, and where to use it and how to evaluate its effect (Garner, 1987). Offering tasks that stimulate engagement, guiding the use of SRL strategies, keeping a record of students' progress, and monitoring their learning process are considered to be important roles of a teacher in promoting self-regulation in the language classroom. According to Zimmerman and Shunk (2001), feedback given by the teacher is the single most important feature in developing students' self-regulation strategies.

A carefully designed learning environment can foster students' self-regulation as well (Zimmerman, 1989). Generally said, a learning environment should be stress- and anxiety-free, student-centered, and authentic, where the learners are offered plenty of opportunities to practice self-regulation (Paris \& Winograd, 1999). Nakata (2010) claims that in an English classroom, teachers should be aware of their learners' background: they should know their students' language-learning history, their language proficiency level, and preferred learning style and strategies. Furthermore, they should be aware of their students" "attitudes toward learning, the factors impeding their progress and motivation, and the gap between their background and the teacher's own background as a learner and a teacher (e.g., teachers' beliefs, teaching styles)" (p. 6). However, Dam (2000) argues that teachers fail to develop their students' self-regulation for manifold reasons, such as their own insecurity with its implementation, lack of time and material, which might support its development, and because they want to fulfill all the curricular demands and tests.

\section{The Hungarian NCC}

Hungary has a three-level curriculum system comprising the NCC, frame curricula, and local curricula. The current 2012 NCC, similarly to its predecessors (1995, 2003, and 2007), constitutes the highest nationwide level of content regulation document issued by the Hungarian Government. The Frame Curricula are accredited by the Ministry of Human Capacities and are developed on the basis of the NCC. Both these documents provide a framework for schools to develop their local curricula, meaning that the latter types of curricula are developed by schools at institutional level (NCC, 2012). The NCC "defines the valid values, the concept of general knowledge, the definition of knowledge and learning" in public education (NCC, 2012, p. 1) and provides a "theoretical, content-related and methodological basis" of school education, a description of the "main fields and content of the subject areas" taught, and defines the educational phases (NCC, 2012, p. 1).

The document itself is divided into three main parts. The first part, "Content regulation and levels of regulation of educational activity," deals with the general tasks and 
values of public education, describes the development fields and educational goals. Furthermore, it provides a comprehensive description of the aforementioned three-level curriculum system dealing with each of these levels - NCC, framework curricula, and local curricula - separately. The second main part "Competence development, the dissemination of general knowledge, knowledge acquisition" sets out key competences and offers some guidelines as to how they should be acquired; in other words, the required abilities, skills, knowledge, and attitudes are highlighted. In addition, it offers a description of the 10 subject areas: (a) Hungarian language (Hungarian); (b) Foreign languages; (c) mathematics; (d) man and society including history, ethics, homeland, and peoples; society, citizenship, and economy; philosophy; (e) man and nature including environment, biology, physics, and chemistry; (f) The Earth, our environment; (g) arts including music, drama, and dance; visual culture; video culture and media literacy; (h) IT studies (IT); (i) way of life and practical skills; and (j) physical education and sports. It characterizes the structure of each subject area and recommendation of the percentage rates for each subject area is offered. The material, principle, goals, development tasks, and general competencies are highlighted and are organized along the three phases of education: the phase of primary education (Grades 1-4 and Grades 5-8) and the phase of secondary education (Grades 9-12). The third main part is basically a glossary of the terms and definitions pertaining to content regulation.

\section{METHODS}

\section{Research question}

In line with the purpose of my research described in the introduction, and after reviewing the literature, the research presented in this paper seeks to answer the following question:

$R Q 1$ : What kind of teachers' roles can be identified in relation to the development of self-regulation based on Zimmerman and Moylan's model?

RQ2: How do English teachers report on the development of their own and their students' self-regulation in the Hungarian public educational sphere?

In order to answer the research questions above, a qualitative method was adopted involving face-to-face, semi-structured interviews.

\section{Participants}

All of the participants volunteered for the interviews in response to an e-mail recruiting Hungarian English language teachers who were willing to share their ideas about their language-teaching experience. An important issue to highlight here, which might have an effect on the interview results, is that all these teachers completed their mentor training just before the interviews and hold a certificate to that effect. Table 2 summarizes the relevant characteristics of the participants.

Four interviews were conducted for this pilot study during the spring term of the academic year 2017-2018. The pilot sample consisted of four Hungarian English language teachers. The average age of the participants was 38 years and the average length of their teaching experience was 12 years (for further details, see Table 2). I tried to achieve maximum variety in sampling the participants; therefore, in selecting the interviewees, I considered their age, gender, teaching experience, and the type of school they work in.

\section{Instrument}

The interview questions were developed specifically for the purpose of this study (see Appendix). The interview guide used in this pilot research was compiled on the basis of the relevant self-regulation literature (Nakata, 2010; Ushioda, 2003; Zimmerman \& Moylan, 2009; Zimmerman \& Shunk, 2001) and the NCC. The semi-structured interview guide, as the main data-gathering device, turned out to be essentially helpful, capturing the complexity, and diversity of the participants' views. The interview questions were written in Hungarian, as the interviews were conducted in the mother tongue of the participants. It is important to note that the quotes from the interviews in this paper were translated into English by the author and the translations were doublechecked by a colleague. The interview guide consisted of 15 questions, which focused on four main topics: Englishteaching experience, roles of an English teacher, effective English language learning, and self-regulation development. Questions dealing with self-regulation development were intentionally left to the end as I was afraid that these might influence the participants' responses and their perception of and attitudes toward this topic. However, it is interesting to note that during the first phase of the interviews, many selfregulation related issues emerged.

\section{Data collection and analysis}

In this pilot study, a qualitative method was adopted involving face-to-face, semi-structured interviews. In the first stage of the research, I conducted interviews with Hungarian English language teachers. The interviews were audiorecorded with the consent of the participants and transcribed verbatim. The interview transcripts yielded about 40,000 words of data, which were analyzed by the researcher for

Table 2. Overview of the participants' biographical data

\begin{tabular}{lcccccc}
\hline Name & Gender & Age & Teaching experience & Subject(s) & Type of school & Teacher's grades \\
\hline 1. Kinga & Female & 39 & 14 years & English & Primary & $1-6$ \\
2. Eszter & Female & 53 & 20 years & English/Hungarian & General secondary school & $9-13$ \\
3. Zoltán & Male & 33 & 8 years & English & Secondary vocational school & $9-10$ \\
4. Erika & Female & 29 & 6 years & English/German & General secondary school & $9-13$ \\
\hline
\end{tabular}

Note. The names are pseudonyms. 
emerging themes. The analysis of the transcribed interview data was built on the traditions of the constant comparative method proposed by Maykut and Morehouse (1994) with the help of the ATLAS.ti 7.5.7 qualitative data analysis software (Berlin, Germany). To sum up, I relied on the continuous comparison of newly identified codes with the already established ones. Things were considered emerging when they were mentioned by at least three of the four interviewees. In the second phase, I compared the results of the interview study with the self-regulation-related guidelines of the Hungarian National Curriculum, which was primarily used as a means for gaining additional information on the topic. The document was analyzed using the constant comparative method (Maykut \& Morehouse, 1994) to identify the key themes related to the conceptualization and integration of SRL. The document was coded inductively with higher levels of abstraction (bottom-up coding) achieved through multiple readings.

\section{RESULTS AND DISCUSSION}

The study sought to investigate the roles the teachers play in promoting their own and their students' SRL. The results are presented based on Zimmerman and Moylan's (2009) SelfRegulation Model, following and drawing parallels with the three phases of their model: the forethought phase, the performance phase, and the self-reflection phase. Based on the interviews, I identified roles that might be assigned to one of the three phases and can be directly or indirectly linked to the development of self-regulation. From the teachers' point of view, the first phase concerns the lesson planning stage, which precedes an English language lesson, and represents the forethought phase. The second phase is the actual English language lesson, the performance phase, which is followed by the self-reflection phase happening after the lessons (see Fig. 2 for a summary).

\section{Roles related to the forethought phase}

Based on the participants' answers, it is evident that even the lesson planning stage includes many elements, which might
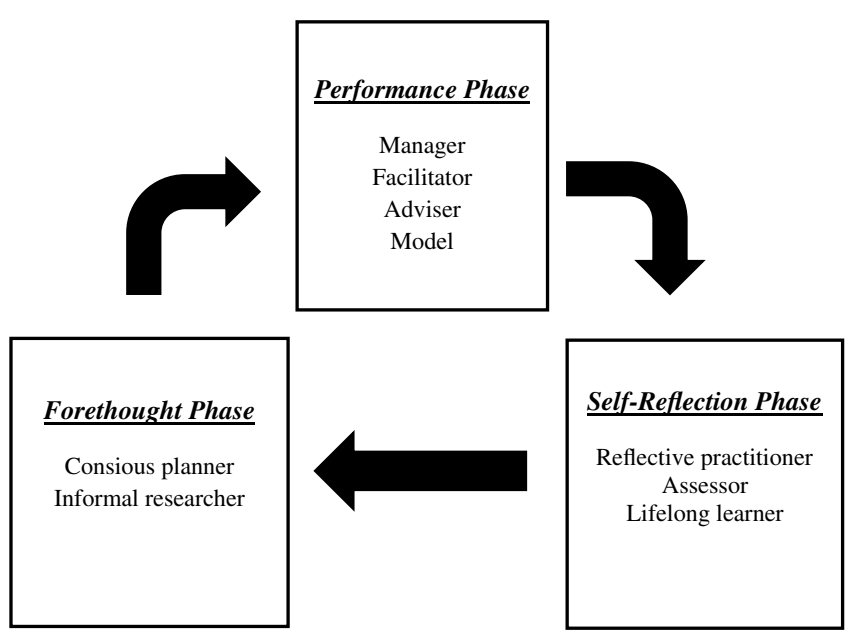

Fig. 2. Identified roles following Zimmerman and Moylan's (2009) Model foster the development of self-regulatory skills. These elements, however, have an indirect effect on students. All four participants said that they carefully construct all their lessons in advance because they find it important to bring a sense of order into their English language classes. Therefore, their first role lies in conscious lesson planning. For the interviewees, an English lesson is like a journey, which shows students where you start, where you finish, and the route to take to get there. According to the teachers, this is highly important as this way students might consciously or unconsciously develop their personal understanding not just of teaching, but of learning as well.

Developing students' learning to learn skills requires constant learning from the teachers' side; consequently, it is a learning process for teachers as well. CPD turned out to be essential as it helps teachers to refine their instructional strategies required to teach these skills. This CPD angle is prevalent in the participants' answers. As Zoltán described his own teaching career: "It is my responsibility to be prepared for the lessons and also to be able to teach well, what I am supposed to teach...to be open to improvement." Erika characterized herself in the following words:

"I try to be open to new methodologies and new things [...], I wish to improve myself continually, like as I have taken all these training courses regularly, and now I came up with the idea of being a mentor teacher to open new perspectives." (Erika)

In the teachers' unanimous opinion, it is the school's task to teach learning skills, which is in complete harmony with the guidelines of the NCC: "Teaching students to learn is a basic task of schools. Every teacher is entrusted to encourage interest in the subject he or she teaches and to orient students in the acquisition, structure and access to the study material" (NCC, 2012, p. 12). However, according to Eszter, even if she finds it important, due to excessive workload and constant pressure, there is simply no time to deal with teaching these skills. She expressed her opinion about this in the following way: "You do not have time and energy to deal with those things that you enjoy, and the students would also benefit from."

Differences arise in part because teachers define this concept differently. Zoltán, for example, interprets the learning to learn skill as a kind of brainstorming, in which the teachers' main role lies in bringing together techniques and methods. As he stated: "I mean, if something is unclear, being ready to approach it from another point of view, or if something has not worked well, you can accomplish it with appropriate tools, repetitions, or other tasks." According to Kinga and Erika, it is more about discovering and raising awareness of the diversity of learning strategies and styles from which students can choose, meaning that teachers strive to get their pupils to choose from the given examples and to apply them appropriately. It seems like they believe in teaching self-regulation skills through modeling them. In addition, the female participants see their main role in leading individual students to choose those learning methods and techniques, which suit them. As Kinga and Erika stated: 
"That would be the ideal situation ... when a child is unconsciously capable of selecting a method that is the most convenient and works best for him/her. When he/she is able to articulate: this or that is better for me, I learn faster by doing it one or the other way." (Kinga)

"After a while, it will be clear what works best for him/ her. I am not so sure if we should intervene that much in this phase, but it is very important to give them tools and opportunities that they can use." (Erika)

The interview extracts show that the concept - learning (how) to learn - is on the one hand about improving learning and on the other hand about teaching. Additional differences arise about how and when to pursue these goals in different classrooms and contexts. Eszter added an interesting fact that in her view, teaching the learning to learn skill requires a separate profession, which idea has never been researched before. In addition, she touched upon a frequently emphasized problem in self-regulation literature, in which the development of self-regulation does not happen in isolation, but is a collaborative activity. As she stated:

"... it is an extra profession, in my opinion. I can very well try to hand on effective learning methods to them. Methods I have experienced during these years and which work the best. I know what I will ask them in a test and while preparing for it I can guide their learning process and make them focus on the essentials. But in my opinion, this requires either an extra profession or I don't know." (Eszter)

Furthermore, participants disagree about when to start the development of learning to learn skills. Two participants argued that the development should start at a later age, as only older learners are capable of autonomy. Kinga, who teaches in an elementary school, tries to lead her students within her lessons, but they are, in her view, still too young to understand its importance. She described the experience in the following words, "they [younger students] are not trying to learn differently at this age, though I lead them ... in the 6th grade, not so much." In Erika's secondary school, in the 9th grade, there is a special learning methodology lesson integrated into the curriculum, but she believes that it is still too early to deal with these skills. She thinks that students become aware of their own personal learning styles later.

"A general note, made not only by me, is that it is all right that it is presented in 9th grade, but it would be a lot more convenient to introduce it to the children later, once they are a bit older... I think they would get a better understanding of the importance of the issue. In 9th grade they chill there, do many exercises that are highly gamificated, but if they were ... so if they looked at the tasks to be completed with different eyes they might learn a lot more from these exercises." (Erika)

Their view seems to match the literature, thus the development of the learning to learn skills requires - at first - the acquisition of the fundamental basic skills, such as literacy (reading and writing), numeracy, and ICT skills, which play a pivotal role in the further learning process (Key Competences for Lifelong Learning, 2006/962/EC).

While two participants', Eszter's and Zoltán's, views are contrasting, the development of the learning to learn skills should start as early as possible at primary school. Zoltán, for instance, indicated: "It is obvious that I point [learning methods] out as often as possible and I do repeat myself all the time again and again [...] it would be very useful to focus more on them already at elementary school level." Eszter described the problem this way, "One would expect us to do so, but we do not cooperate with my colleagues and it would be essential to teach this to children gradually from the very beginning." The literature seems to support their position as well and highlights it that the development of self-regulation should start as early as age 3 (Nagaoka et al., 2015). After analyzing the NCC, it is evident that the issue of when to start the development of the learning to learn skills is completely neglected. However, the interviewees' answers and the NCC imply that for effective learning to learn skill development it is important to know your students. But how much do teachers know about their students? Is it possible to get to know your students at all?

The literature highlights that many people underestimate the importance of "knowing your students" as either a "vacuous platitude" or a "statement of the obvious" (Powell \& Kusuma-Powell, 2011, p. 21). The participants all agreed that their students are completely different. These differences include, but are not limited to, the students' level of motivation, behavior, and attitudes about teaching and learning. Furthermore, they emphasized that by knowing their students' strengths and weaknesses, and figuring out their degree of autonomy and independence, it is much easier for teachers to teach their students' how to learn. The participants outlined that knowing your students is challenging and difficult but not impossible. In fact, according to Erika, teachers know a lot more about their students than they would expect. As she explained:

\begin{abstract}
"I know what kind of people they are, though they don't think I know them very well. [...] Well, I definitely need to add that in my opinion, we know a lot more than they would expect. We make assumptions from how they behave and how they express themselves... a lot can be found out about a person this way." (Erika)
\end{abstract}

The participants emphasized that knowing students means more than knowing their names, ages, school friends, and their academic achievements; in order to help their leaning, the teachers have to examine students more carefully. Teachers have to take up a kind of informal researcher role. Erika, a form teacher, mentioned that the parent meetings are another way to get some information about her students. As she puts it: "It is also very interesting to get feedback from the parents... how they see it: what a child has already achieved and learned or not learned, compared to how I see it."

According to the interviewees, the quality of the school work and homework is an effective tool for teachers to get to know their students better. Kinga emphasized that there are students who are more open to sharing their stories with 
the teacher. There are students who talk about how things are at home, because it is a topic they like, some of them are quieter. The shy ones would not talk about it - in their cases, she sees how much extra effort is made at home to improve their English from their work at school. Furthermore, the importance of teaching the learning to learn skills was also primarily mentioned in the context of home learning by the interviewed teachers; that is, the development of the learning to learn skill improves the quality of home preparation.

The participants find it extremely important to establish a solid relationship with their pupils as it may allow them to better differentiate for individual needs. All the teachers emphasized that as their students develop at different rates, differentiated instructions are essential to provide the best learning experience possible. They personalize the learning for their students, which begins with knowing them. Individualization and differentiation are also emphasized throughout the NCC, and "discovering individual learning problems and promoting their solution throughout the process of school education and in all its fields" is highlighted as one of the main principles of assisting successful learning (NCC, 2012, p. 13). The NCC as well as the participants recognizes that it is impossible to teach well without knowing your students.

\section{Roles related to the performance phase}

This section presents those roles, which are linked to the actual English lessons. The most significant role is the one of the classroom managers. The interviewees highlighted that they are constantly trying to raise awareness of the elements that appear in their own teaching culture, thereby giving the students a sense of security. As Kinga emphasized:

"I like it when the main stages of a lesson are present in my English classes. It does not always end... its arc is not always so beautiful, but I like it when my students sense and know what to expect." (Kinga)

Another common feature is that, during a lesson, teachers consciously plan their classroom management and try to minimize frontal work. They use individual, group, and project works. This was echoed by Erika:

"I try to vary pair work, group work and individual work... these can all be very effective. I try to avoid frontal teaching, which is not necessarily in fashion any more, I do not really know what my older colleagues... how they teach, but I try to minimize frontal teaching." (Erika)

The NCC also highlights the importance of using various organizational forms of education and techniques. The learning environment must be "organized in a manner that supports various types and techniques of active learning in harmony with the composition and size of the study group and with the available conditions" (p. 96). However, the answers also reveal that this cannot always be accomplished, mainly because of the arrangement and the equipment of the language classrooms. Zoltán remarked:
"Unfortunately, the classrooms ... many times, we have many classrooms, somehow I do not know why... there are computer desks and these are fixed tables, so it is not possible to move them."

The interviewees put special emphasis on creating a learning environment where students feel that they are being heard and appreciated, which promotes the development of self-regulatory skills. Teachers act as facilitators. The participants highlighted the importance of an anxiety-free, pleasant, receptive atmosphere in an English class to make the student feel comfortable. Using humor was mentioned by all four participants as an effective tool to achieve a relaxed atmosphere. An additional recurring element is goal setting, which enables students to see what they learn and how this relates to the previous curriculum, so as to create a kind of "flow experience" (see Csikszentmihalyi, 1975). An example of this is as follows:

"So it is very important to remember the content of the previous lesson and to build on it. It's incredibly important for the kids to see that we are going somewhere and not just into the desert, but there's a specific goal we want to achieve." (Kinga)

This angle is also present in the NCC, which states that creating a positive attitude toward learning presupposes an "inner motivation [...] the ongoing maintenance of which is conditional upon the use of prior learning and life experience, search for new learning opportunities and the wide use of what one has learned in all spheres of life" (p. 26). This quotation also implies a sense of autonomy, which was a recurring theme during the interviews. All the participating teachers highlighted autonomy as a key factor of language learning. I was interested in how teachers define the notion itself. An interesting observation was that most of the participants immediately started their definition by describing an autonomous learner, which might be caused by the fact that they had a hard time defining autonomy itself. As Zoltán gave an English language learning example and explained: "Autonomy is when he/she [a student] says: I looked up the words at home. I did not understand the task, but I looked up the words. "Even if his definition implies a sense of responsibility, and choosing direction for learning, it is basically a learning strategy he highlighted, which constitutes just a small segment of autonomy. Kinga had a much broader definition of the term, but her explanation is essentially the same as Zoltán's. Her definition is very accurate and in line with definitions of learner autonomy presented in the relevant literature.

"... that I see in a given situation what can be done and I do it. This is what I call autonomy. I can do it for myself, for someone else or have a noble goal. The most important thing is that I can decide for myself what to do in that situation and I go for it." (Kinga)

For example, she highlighted the notions of goal-setting, interdependence, taking charge, and pursuing one's goals. The following subthemes emerged as participants tried to present their definition of autonomy: being responsible, independent, and motivated. Eszter added to her own 
definition that her students are not autonomous enough, as they expect too much from her. The following comment clearly illustrates this conviction:

"Students should be consciously raised to be autonomous. They should not expect their teachers to tell them what to do in class while vegetating like a zombie. [...] They have to be told too much. They should work a bit harder, think a bit further and have ideas about their own needs and problems without me having to guess them." (Eszter)

The participants' definitions of autonomy involve autonomy both inside and outside of the classroom practice, pertaining to home preparation and help-seeking. A strong point emphasized in the literature review is the strong connection between the learners' social context and self-regulation; therefore, I addressed a question on how participants' view help-seeking. Zoltán indicates that students lack a sense of perseverance; even if his students ask for help, they expect immediate results. As he states:

\begin{abstract}
"Because they expect instant results. They are thirsty for immediate results from studying one day and achieving something the next day, immediately. It is hard this way... if a student seeks help from me, I see it even from the way he/she asks for it: let it happen the same day they ask, right now, quickly, if possible. They are not willing to invest a lot of energy into it." (Zoltán)
\end{abstract}

The interviewees encourage students to learn from external sources and, if necessary, to use aids. They put on an advisory role. The participants encourage their students to expose themselves to as much English language as possible; English movies, TV series, videos, music, with or without English subtitles were mentioned. They advise the usage of mobile applications and online proficiency and language tests. From the self-regulation perspective, the NCC highlights the importance of teaching students how to search for information in a number of sources and how to evaluate the reliability and objectivity of the newly acquired information. Students should be given access to extra materials, tools, and library resources in order to provide them with opportunities for independent learning.

However, there are differences in how teachers view external help, for example, parental help. According to Kinga, who teaches in an elementary school, the assistance from parents is very important. The remaining participants the high school teachers - had a different opinion on the issue. According to them, parental support in this age group, in addition to being "not cool," hampers rather than facilitates preparation. According to Erika and Eszter, the development of students' autonomy might be negatively affected. As Eszter stated: "They no longer belong to that category, they are big ... they are more independent, more serious personalities, they do not ask for help." Erika echoed a similar view:

"I do not have kids, I have to add, I do not have my own experience, but in a higher class, I think the main goal is to try to learn independently as much as possible... asking parents ... I do not think so. If he is able to go to parties on his own, then he should be able to write his homework by himself." (Erika)

Zoltán added that the relationship between parents and their children has undergone a kind of change that affects the students' studies negatively. As he summarized this in the following words:

"I see an interesting, but sad phenomenon nowadays: a mother/father acting more like a buddy than a parent. It has already occurred that I asked a pupil: Why didn't you ask your mother/father? It is incredible, but some answered: Oh, we went shopping instead. That means the parents do not help; what is more, they hinder their children." (Zoltán)

The NCC stresses that taking control of one's learning, such as the acquisition, processing, and assimilation of new knowledge; searching for new learning opportunities; asking for advice and support, if necessary, are regarded to be essential for lifelong learning. The document highlights that "learning must be organized in a way that ensures the active participation of students, focuses on their activity, independence, initiatives, problem solving strategies and creativity" (NCC, p. 13). According to the NCC, independent learning requires the learner to be aware of their own strengths and weaknesses and the ability to use those opportunities, guidance, and support that are available to them. The use of ICT tools, writing, reading, and numeracy are essential for independent learning. Students must be offered many opportunities to perform tasks independently, and they must learn the use of sources (dictionaries, manuals, grammar textbooks, practice materials, electronic sources, etc.) that may help them in independent work.

\section{Roles related to the self-reflection phase}

Two roles were identified in relation to this phase: being assessors, so giving/getting feedback and being reflective practitioners, in other words, reflecting on the whole teaching and learning process. The interviewees highlighted that, with the help of feedback, students become aware of their attitudes toward studying certain subjects. The feedback provided by the teacher makes the learning process visible and helps students to understand (a) what they are expected to learn, (b) what they have already learned, and (c) how they can promote their own learning and improve their performances. Therefore, receiving and giving feedback positive and realistic - are considered to support learning and reinforce pupils' trust in their potential. Their response highlights that feedback is not exclusively given by the teacher. The interviewees underlined that they frequently ask their students to evaluate each other's work, but evaluating their own work does not happen very frequently. Both Zoltán and Erika stated that self-evaluation happens spontaneously. Zoltán explained that "it is not a planned part of my lessons, it happens impromptu." Erika reacted in this way, "well, I don't really ask them to do it... however they slip out a lot, where they evaluate themselves" They 
admitted that they find self-evaluation important but somehow they forget or do not often think of this aspect of evaluation during their English lessons. It is interesting to note that while the NCC stresses the importance of cooperation and working with others, peer-assessment is not included in its content. The NCC outlines only selfassessment and feedback given by the teacher. The NCC says that teachers must provide feedback on students' work on a regular basis and students must learn to reflect on their learning process and judge how well they have performed in relation to the assessment criteria.

The participants also emphasized that they frequently ask their students to give them feedback about the teaching process not just after the lesson, but during a lesson. These results are also consistent with the literature. Schön (1983) created his self-reflection theory based on the time frame of reflection. He established two basic types of reflection: reflection-on-action and reflection-in-action. Reflectionon-action is basically about reviewing a past event, so it is an after-the-event thinking, whereas reflection-in-action happens while doing something, so reflection takes place during the event. The teachers find their colleagues' and other people's feedback and guidance valuable. They stated that based on the received feedback they change and shape their subsequent lessons. However, every teacher has a "professional maturity," so it is everyone's own decision "to decide whether or not to take this advice on board" (Stonehouse, 2011, p. 301). Therefore, it is evident that teachers are lifelong learners and CPD helps educators incorporate new tools and strategies into their teaching process to boost their students' learning development. Reflection is very useful, not only for in-service teachers, but preservice teachers as well, as it can improve teachers' effectiveness in the classroom by bringing an awareness of the need for change. It is through this change that learning and development occur. This is also the point where we get back to the first, forethought face, ending and starting the next self-regulating circle.

\section{CONCLUSIONS}

In this paper, I examined Hungarian English language teachers' roles in promoting SRL by means of four pilot interviews. The participants seemed to be concerned about the development of their students' self-regulation and were well aware of its importance. As Dembo (2001) highlighted, teachers who are self-regulated - and are aware of what selfregulation means - might be more open to foster these skills within their students. Therefore, we can look at teachers as lifelong learners, who are responsible for their own selfregulation, while developing someone else's. For that reason, a self-regulated teacher shows the same characteristics as a self-regulated learner (see sections "Teachers as selfregulated learners" and "Roles of a teacher"). The existing literature (e.g., Butler, 2003), as well as this study, emphasized that (adult) learners need self-motivation for learning, an inner willingness for personal development, self-awareness, a positive attitude, and willingness to motivate and support others to develop their own learning.
If we compare the results with the list of the basic constituents of self-regulation (Zimmerman \& Moylan, 2009) and the effective ways of fostering it (Nakata, 2010; Ushioda, 2003), we can find a large overlap, not to mention that the NCC seems to offer a firm based on the topic as well. Following Zimmerman and Moylan's (2009) model, a link was drawn between its phases and the identified roles of the teachers. I was able to identify different roles teachers play in fostering their own and their students' self-regulation. The results suggest that teachers find both the direct (showing students how to use certain tools, pointing out different learning strategies, and assessment) and indirect promotion (careful lesson planning and knowing your students) of self-regulation important.

The first two roles are related to learning, namely learning how to learn and teaching how to learn. The results suggest that developing student's self-regulation requires individual as well as shared learning from the teachers' side. As they pointed out learning from colleagues, cooperation and making school level decisions together about the development of self-regulation would be ideal; however, it does not actually happen. As one of the participants highlighted that teachers do not really work together because of time constraints and simply they have no time to deal with those issues, which might benefit both the students and the teachers.

It is clear from the results that when talking about learning to learn teachers refer to more explicit and strategic instructional procedures, but fostering the development of self-regulation mainly happens in an indirect way, by conscious lesson planning, for example, assigning more importance to the learning environment. The results indicate that teachers pay attention to designing constructivist learning environments to foster the development of their students' self-regulation. They consciously work on creating a relaxed atmosphere where students feel confident and even let them use mobile devices to teach them how to use these modern technologies in a responsible manner. However, the first striking difference occurred between the participants' views on when to start the development of the learning to learn skills. Two participants emphasized that it should start as early as possible, while two of them said that even if they try to lead their students to learn differently, the latter do not understand or want to change their learning habits and strategies because they do not see the point. These latter two participants would start developing learning skills at an older age. One of the participants went further and explained that development of the learning to learn skills would require a separate profession.

The effective development of self-regulation skills requires a certain degree of knowing your students, which requires that teachers work as informal researchers. The teachers summed up that they get information about their students from different sources including their school work, the way they ask questions and express themselves, the quality of their homework, and the students' parents. They use this information to differentiate and individualize the learning experience.

According to the participating teachers, successful learning requires individual effort and the help of others. There are many different types of help students can request - emotional, 
instrumental, and technical support - which greatly depends on the students' characteristics. The teachers highlighted that help-seeking also tells a lot about students and greatly exemplifies how they regulate their own learning. The use of IT tools, dictionaries, watching movies/TV series, and listening to music with or without English subtitles are greatly emphasized during English classes. Parental assistance, however, is a controversial issue, as some view it as a hindrance rather than an effective help. As one of the participants mentioned, the student-parent relationship has changed recently and a kind of "buddy" culture emerged between the parents and their children, which brought the child-parent relationship to a whole new level. One of the participants also highlighted that students want immediate results, they give up so early, and they are impatient and starve to get immediate results.

As the last roles, getting and giving feedback and (self) reflection were emphasized, by which teachers go back to their initial role and try to reevaluate their teaching. The participants believe that these might raise their students' awareness and ability to incorporate the most suitable learning strategies into their daily learning process and make them self-regulated learners. The question is whether the positive picture that has appeared in this study is really true or whether it reflects ideas of how teachers should think.

Public education plays a huge role in our life. Despite its numerous advantages, many people think that the educational system is too old-fashioned, following and operating on similar principles to schools, which existed hundreds of years ago. These institutions, which are far from the needs of the 21 st century, do not prepare students well enough for everyday challenges (Collom, 2005; Pell, 2014). Based on the results, it is clear the participants are fully aware of the importance of developing self-regulation and even the NCC contains some aspects of SRL.

However, according to teachers, students still seem to expect too much from their teachers. Further studies - additional interviews with teachers, parents, and students - are needed to determine the main causes and the reasons for this. As the main limitation of the study, I would highlight this, the missing perspective and voices of students, to see how the various voices fit together. In addition, classroom observations could provide a much more comprehensive picture of teachers' behavior with regard to fostering students' self-regulation. Another limitation which should be highlighted here is that the questions did not focus on the teachers' own self-regulation and its development. Using interview guide, I gathered insightful data on how teachers view and develop their students' self-regulation but failed to deal with the topic's personal angle. Follow-up interviews with these teachers about their own self-regulation and the ways they developed these skills would further develop and confirm these initial findings.

It is important to note that the way children are taught not only determines their own future but also widens their possible contribution to the community they are going to live in. For this reason, it is in the interest of each government to develop curricula, which would include some effective ways of integrating self-regulation into teaching - mainly teacher training - and face the new challenges arising with the passage of time.
Funding sources: None.

Author's contribution: The author has full access to the references included in this analysis and takes responsibility for the integrity and accuracy of the study.

Conflict of interest: The author declares no conflict of interest.

\section{REFERENCES}

Ainsworth, H. L., \& Eaton, S. E. (2010). Formal, non-formal and informal learning in the sciences. Calgary, Canada: Onate Press. Retrieved December 20, 2018, from http://en.copian.ca/ library/research/eaton/sciences/sciences.pdf

Barry, K., \& King, L. (1998). Beginning teaching and beyond. Katoomba. Katoomba, Australia: Social Science Press.

Baumeister, R. F., Leith, K. P., Muraven, M., \& Bratslavsky, E. (1998). Self-regulation as a key to success in life. In D. Pushkar, W. Bukowski, D. Stack, A. Schwartzman, \& D. White (Eds.), Improving competence across the lifespan (pp. 117-132). New York, NY: Plenum.

Boekaerts, M., \& Corno, L. (2005). Self-regulation in the classroom: A perspective on assessment and intervention. Applied Psychology: An International Review, 54(2), 199-231. doi:10.1111/j.1464-0597.2005.00205.x

Boekaerts, M., \& Niemivirta, M. (2000). Self-regulated learning: Finding a balance between learning goals and ego-protective goals. In M. Boekaerts, P. R. Pintrich, \& M. Zeidner (Eds.), Handbook of self-regulation (pp. 417-450). San Diego, CA: Academic Press.

Boekaerts, M., Pintrich, P. R., \& Zeidner, M. (Eds.). (2000). Handbook of self-regulation. San Diego, CA: Academic Press.

Borg, S., \& Al-Busaidi, S. (2012). Learner autonomy: English language teachers' beliefs and practices. London, UK: The British Council. Retrieved December 14, 2018, from http:// www.teachingenglish.org.uk/publications

Butler, D. L. (2003). Self-regulation and collaborative learning in teachers' professional development. Paper presented at the 2003 annual meetings of the European Association for Research in Learning and Instruction (EARLI), Padova, Italy.

Calderhead, J. (1989). Reflective teaching and teacher education. Teaching and Teacher Education, 5(1), 43-51. doi:10.1016/ 0742-051X(89)90018-8

Carneiro, R., \& Veiga Simão, A. M. (2011). Technology enhanced environments for self-regulated learning in teaching practices. In R. Carneiro, P. Lefrere, K. Steffens, \& J. Underwood (Eds.), Self-regulated learning in technology enhanced learning environments: A European perspective (pp. 75-101). Rotterdam, Netherland: Sense Publishers.

Cohen, A. D. (1990). Language learning: Insights for learners, teachers, and researchers. New York, NY: Newbury House.

Collett, P. (2014). Researching self-regulated learning and foreign language learning. Studies in Self-Access Learning Journal, 5(4), 430-442.

Collom, E. (2005). The ins and outs of homeschooling: The determinants of parental motivations and student achievement. 
Education and Urban Society, 37(3), 307-335. doi:10.1177/ 0013124504274190

Csikszentmihalyi, M. (1975). Beyond boredom and anxiety. San Francisco, CA: Jossey-Bass.

Dam, L. (2000). Why focus on learning rather than teaching? From theory to practice. In D. Little, L. Dam, \& J. Timmer (Eds.), Papers from the IATEFL conference on learner independence, Kraków (pp. 18-37). Dublin, Ireland: CLCS, Trinity College Dublin.

Dembo, M. H. (2001). Learning to teach is not enough: Future teachers also need to learn how to learn. Teacher Education Quarterly, 28(4), 23-35.

Demetriou, A. (2000). Organization and development of selfunderstanding and self-regulation: Toward a general theory. In M. Boekaerts, P. R. Pintrich, \& M. Zeidner (Eds.), Handbook of self-regulation (pp. 209-251). San Diego, CA: Elsevier Academic Press.

European Parliament \& Council of the European Union. (2006). Key competences for lifelong learning (2006/962/EC). Official Journal of the European Union, L394, 10-18.

European Parliament \& Council of the European Union. (2018). Key competences for lifelong learning. Retrieved December 25, 2018, from https://eur-lex.europa.eu/legal-content/EN/TXT/? uri=CELEX:52018DC0024

Freire, P. (1993). Pedagogy of the city. New York, NY: Continuum Books.

Fleming, T. (2011). Models of lifelong learning: An overview. In M. London (Ed.), Oxford handbook of lifelong learning (pp. 29-39). New York, NY: Oxford University Press.

Garner, R. (1987). Metacognition and reading comprehension. Norwood, NJ: Ablex.

Gordon, S. C., Dembo, M. H., \& Hocevar, D. (2007). Do teachers' own learning behaviors influence their classroom goal orientation and control ideology? Teaching and Teacher Education, 23(1), 36-46. doi:10.1016/j.tate.2004.08.002

Hadwin, A. F., Järvelä, S., \& Miller, M. (2011). Self-regulated, co-regulated, and socially shared regulation of learning. In B. J. Zimmerman \& D. H. Schunk (Eds.), Educational psychology handbook series. Handbook of self-regulation of learning and performance (pp. 65-84). New York, NY: Routledge/Taylor \& Francis Group.

Hoffman-Kipp, P., Artiles, A. J., \& López-Torres, L. (2003). Beyond reflection: Teacher learning as praxis. Theory Into Practice, 42(3), 248-254. doi:10.1207/s15430421tip4203_12

Holec, H. (1981). Autonomy and foreign language learning. Oxford, UK: Pergamon.

Kálmán, Cs. (2018). EFL teachers' motivation and motivational impact in corporate contexts. Journal of Adult Learning, Knowledge and Innovation, 2(1), 33-47. doi:10.1556/2059.02.2018.03

Lemos, M. S. (1999). Students' goals and self-regulation in the classroom. International Journal of Educational Research, 31(6), 471-485. doi:10.1016/S0883-0355(99)00016-6

Little, D. (1995). Learning as dialogue: The dependence of learner autonomy on teacher autonomy. System, 23(2), 175-181. doi:10.1016/0346-251X(95)00006-6

Littlejohn, A., Milligan, C., \& Margaryan, A. (2012). Charting collective knowledge: Supporting self-regulated learning in the workplace. Journal of Workplace Learning, 24(3), 226-238. doi:10.1108/13665621211209285

Maykut, P., \& Morehouse, R. (1994). Beginning qualitative research: A philosophic and practical guide. London, UK: The Falmer Press.
Medgyes, P. (2000). The ventriloquist. News In Brief, 2001(2), 8-18. Retrieved December 14, 2018, from http://www.BetaIatefl.Org/848/Blog-Publications/The-Ventriloquist/

Mesárošová, M., \& Mesároš, P. (2012). Learning to learn competency and its relationship to cognitive competencies of university students. Procedia-Social and Behavioral Sciences, 46(1), 4273-4278. doi:10.1016/j.sbspro.2012.06.240

Michalsky, T., \& Schechter, C. (2013). Preservice teachers' capacity to teach self-regulated learning: Integrating learning from problems and learning from successes. Teaching and Teacher Education, 30, 60-73. doi:10.1016/j.tate.2012.10.009

Montalvo, F., \& Torres, M. (2004). Self-regulated learning: Current and future directions. Electronic Journal of Research in Educational Psychology, 2(1), 1-34.

Nagaoka, J., Farrington, C. A., Ehrlich, S. B., Heath, R. D., Johnson, D. W., Dickson, S., Turner, A. C., Mayo, A., \& Hayes, K. (2015). Foundations for young adult success. A developmental framework. Chicago, IL: Urban Education Institute. Retrieved 7 November, 2018, from https://www.wallacefoundation.org/knowledgecenter/Documents/Foundations-for-Young-Adult-Success.pdf

Nakata, Y. (2010). Toward a framework for self-regulated language-learning. TESL Canada Journal, 27(2), 1-10. doi:10. 18806/tesl.v27i2.1047

National Core Curriculum [NCC]. (2012). Budapest: Ministry of Human Resources. Retrieved June 15, 2018, from regi. ofi.hu/download.php?docID=5846

Öveges, E., \& Csizér, K. (2018). Az idegennyelv-oktatás keretei és hatékonysága a köznevelésben [The framework and efficiency of foreign language education in public education]. Budapest, Hungary: Emberi Erőforrások Minisztériuma és Oktatási Hivatal. Retrieved January 15, 2018, from https:/www.oktatas.hu/pub_ bin/dload/sajtoszoba/nyelvoktatas_kutatasi_jelentes_2018.pdf

Paris, S. G., \& Paris, A. H. (2001). Classroom applications of research on self-regulated learning. Educational Psychologist, 36(2), 89-101. doi:10.1207/S15326985EP3602_4

Paris, S. G., \& Winograd, P. (1999). The role of self-regulated learning in contextual teaching: Principles and practices for teacher preparation. In ERIC Clearinghouse on Adult, Career, and Vocational Education \& ERIC Clearinghouse on Teaching and Teacher Education (Eds.), Contextual teaching and learning: Preparing teachers to enhance student success in the workplace and beyond (pp. 219-253). Columbus, OH/ Washington, DC: ERIC Clearinghouse on Adult, Career, and Vocational Education/ERIC Clearinghouse on Teaching and Teacher Education. Retrieved November 6, 2018, from https:// files.eric.ed.gov/fulltext/ED427263.pdf

Pell, B. (2014). Homeschooling: How parents are influencing education for the 21st Century. Himgiri Education Review, 1(2), 1-9.

Persico, D., Milligan, C., \& Littlejohn, A. (2015). The interplay between self-regulated professional learning and teachers' work-practice. Procedia-Social and Behavioral Sciences, 191, 2481-2486. doi:10.1016/j.sbspro.2015.04.590

Pintrich, P. R. (1999). The role of motivation in promoting and sustaining self-regulated learning. International Journal of Educational Research, 31(6), 459-470. doi:10.1016/S08830355(99)00015-4

Pintrich, P. R. (2000). The role of goal orientation in self-regulated learning. In M. Boekaerts, P. R. Pintrich, \& M. Zeidner (Eds.), Handbook of self-regulation (pp. 451-502). San Diego, CA: Academic. 
Powell, W., \& Kusuma-Powell, O. (2011). How to teach now: Five keys to personalized learning in the global classroom. Alexandria, VA: ASCD.

Randi, J. (2004). Teachers as self-regulated learners. Teachers College Record, 106(9), 1825-1853. doi:10.1111/j.14679620.2004.00407.x

Reinders, H., \& Balcikanli, C. (2011). Learning to foster autonomy: The role of teacher education materials. Studies in SelfAccess Learning Journal, 2(1), 15-25.

Reményi, V. J. (2016). Steps in need of teachers' tranformative professonial learning. Opus et Educatio, 3(6), 768-776. Retrieved from http://opuseteducatio.hu/index.php/opusHU/ article/view/152/219

Schön, D. A. (1983). The reflective practitioner. New York, NY: Basic Books.

Sparks-Langer, G. M., \& Berstein Colton, A. (1991). Synthesis of research on teachers' reflective thinking. Educational Leadership, 48(6), 37-44.

Stonehouse, D. (2011). Using reflective practice to ensure high standards of care. British Journal of Healthcare Assistants, 5(6), 299-302. doi:10.12968/bjha.2011.5.6.299

Smid, D. (2018). Hungarian pre-service teachers' motivation to become English teachers: Validating a questionnaire. Journal of Adult Learning, Knowledge and Innovation, 2(1), 19-32. doi:10.1556/2059.02.2018.02
Ushioda, E. (2003). Motivation as a socially mediated process. In D. Little, J. Ridley, \& E. Ushioda (Eds.), Learner autono$m y$ in the foreign language classroom: Teacher, learner, curriculum and assessment (pp. 90-102). Dublin, Ireland: Authentik.

Zimmerman, B. J. (1989). A social cognitive view of self-regulated academic learning. Journal of Educational Psychology, 81(3), 329-339. doi:10.1037/0022-0663.81.3.329

Zimmerman, B. J. (2000). Attaining self-regulation: A social cognitive perspective. In M. Boekaerts, P. R. Pintrich, \& M. Zeidner (Eds.), Handbook of self-regulation (pp. 13-39). San Diego, CA: Academic Press.

Zimmerman, B. J. (2008). Investigating self-regulation and motivation: Historical background, methodological developments, and future prospects. American Educational Research Journal, 45(1), 166-183. doi:10.3102/000283120 7312909

Zimmerman, B. J., \& Moylan, A. R. (2009). Self-regulation: Where metacognition and motivation intersect. In D. J. Hacker, J. Dunlosky, \& A. C. Graesser (Eds.), Handbook of metacognition in education (pp. 299-315). New York, NY: Routledge.

Zimmerman, B. J., \& Schunk, D. H. (Eds). (2001). Self-regulated learning and academic achievement: Theoretical perspectives. Hillsdale, NJ: Lawrence Erlbaum Associates. 


\section{APPENDIX}

Interview questions:

How old are you?

Where do you live?

How long have you been teaching?

Where do you teach?

How long have you been teaching in this institution?

What subjects do you teach?

Which grade levels do you teach?

1. Describe yourself as an English language teacher!

2. Describe your English teaching style!

3. What do you think the role of an English teacher in the classroom is?

4. How would you characterize your students' responsibilities in the classroom?

5. How would you characterize your students' responsibilities outside the classroom?

6. How do you contstruct your English lessons?

7. What is the most rewarding aspect of your job? What is the most challenging part?

8. What have you found to be the toughest aspect of teaching English?
9. How would you describe your relationship with your students?

10. How would you characterize a successful language learner?

11. Describe effective teaching techniques that result in intended learning.

12. "Teaching students how to learn is the primary task of the school." What do you think about it?

13. How independent are your students concerning English language learning?

(a) What do you mean under the term autonomy?

14. How much do you know about your students' home preparation?

15. What type of advice would you give to a student who wants to develop her/his skills?

(a) Writing skills

(b) Speaking skills

(c) Listening skills

(d) Grammar 